\title{
Disturbance and population structure of Vitex doniana Sw. in northern Benin, West Africa
}

\author{
Madjidou OUMOROU ${ }^{1,2 *}$, Théophile SINADOUWIROU ${ }^{2}$, Martial KIKI ${ }^{1,2}$, \\ Romain GLELE KAKAÏ ${ }^{2}$, Guy Appolinaire MENSAH ${ }^{3}$ and Brice SINSIN ${ }^{2}$ \\ ${ }^{\text {I}}$ Département de Génie de l'Environnement, Ecole Polytechnique d'Abomey-Calavi, \\ Université d'Abomey-Calavi, 01 BP 2009 Cotonou, Bénin. \\ ${ }^{2}$ Laboratoire d'Ecologie Appliquée, Faculté des sciences Agronomiques, \\ Université d'Abomey-Calavi 01 BP 526 Cotonou, Bénin. \\ ${ }^{3}$ Institut National des Recherches Agricoles du Bénin, 01 BP 884 Cotonou, Bénin. \\ * Corresponding author, E-mail: moumorou@yahoo.fr, Tel: 0022995406194
}

\begin{abstract}
Vitex doniana Sw. (black plum) is a species known to have socio-economic potentialities due to its food, therapeutic and cultural uses. The structure and natural regeneration of this species were studied in Banikoara district, in northern Benin. The main objective was to develop strategies for conservation and sustainable use of this species. Collected data focused on diameter, height, number of individuals and regenerations in plots of various sizes according to habitats considered. Degree of threat and the endogenous uses and methods of conservation were also assessed. The results showed that $V$. doniana presented, in general, an aggregative distribution (Blackman Index $=10.84$ ) which was related to its dissemination type and a random distribution in agroforestry parklands (Blackman Index $=0.34$ ) related to management type. The density values of mature and natural regeneration were low. The species suckered well in all habitats and have a relatively stable structure in natural areas. However, $V$. doniana presented a degree of threat respectively equivalent to $62.27 \%$ and $95.65 \%$ in disturbed riparian landscape and in parklands. The various uses showed that fruits and leaves were the most used parts in feeding and in traditional medicine. They are sold in local markets and are not subject to industrial processing.
\end{abstract}

(C) 2010 International Formulae Group. All rights reserved.

Keywords: Structure, regeneration, black plum, conservation, Banikoara, Benin.

\section{INTRODUCTION}

Forests provide a variety of timber and non-timber forest products including firewood, medicinal plants, flowers, fruits, leaves, roots that contribute to the household economy, strengthen food security and conservation of biological diversity (Eyog Matig and Ouédraogo, 1999; Eyog Matig et al., 2002; Nyadoi, 2005; Sinsin et al., 2004). For many rural community, food harvested from the forest or trees are critical to ensure a complete diet, and provide needed source of protein, calories and essential vitamins for healthy; and this more crucial during food shortage seasons. Forest foods provide people with the opportunity to bridge the gap 
between food shortage and next crop harvest; and they play an important role in the global food system, in case of disasters (floods, droughts, famines and wars) (FAO, 2006 a).

Vitex doniana, a monostem species, is a particular tree with a large socio-economic value in Benin and specifically in the Banikoara district. Physico-chemical and sensory results indicate that the syrup of Vitex doniana can substitute for other syrups as a nutritive sweetener (Burkill, 2000). In the study area, this species is often pruned by local people to provide with vegetables and fruits. These mutilations give rise to serious restlessness about the capacity of regeneration of this species and compromise, therefore, the policies of sustainable conservation. The success of the restoration of $V$. doniana populations and its sustainable use requires better knowledge of these populations and their various modes of regeneration.

In this study, we investigated the structure and regeneration of $V$. doniana populations in disturbed and non disturbed habitats around the National Park W (Banikoara district). It aims at characterizing the spatial distribution of trees, to study the natural regeneration, to identify the degree of threat on Black plum populations and to identify the various uses by people of Banikoara district.

\section{MATERIALS AND METHODS Study area}

The study was carried out in the Banikoara district of the Transboundary Biosphere reserve of ' $\mathrm{W}$ " $\left(11^{\circ} 20^{\prime}-12^{\circ} 23^{\prime} \mathrm{N}\right.$; $2^{\circ} 04^{\prime}-3^{\circ} 05^{\prime} \mathrm{E}$ ) in Benin, West Africa (Figure 1). Banikoara district is in the SudanoSahelian climatic region characterized by a rainy season from May to September and a dry season from October to April. The mean annual rainfall is about $1,000 \mathrm{~mm}$. The vegetation in the study area is composed of shrub tree savannah, woodland, edaphic saxicolous vegetations and to a lesser degree, of dry forests, riparian forests where $V$. doniana mostly occurs. The human population of Banikoara district is estimated to 152,028 inhabitants and is predominantly rural with several socio-cultural groups dominated by Baribas (69.90\% of the population) and Peulhs (22.7\% of the population). The most common activities in the area are agriculture (corn, cotton, sorghum and cowpeas farming), livestock (cattle), fishing, local trade of crops and forest goods, firewood exploitation and craft industry.

\section{Methods}

\section{Forest inventory and ethnobotany}

Data were collected in three types of habitats with different disturbance levels: undisturbed riparian forests, disturbed riparian forests and agroforestry parklands. Plots size varied from one habitat to another (Table 1) and investigations were focused on tree inventory of total number of adult individuals $(\mathrm{DBH} \geq 5 \mathrm{~cm})$, circumference at $1.3 \mathrm{~m}$ above the round, the total height, number of regenerations $(\mathrm{Dbh}<5 \mathrm{~cm})$ and total number of individuals maimed and cut down.

As regards the socio-economic importance of the species, structured interviews were done with a questionnaire prior to a semi-structured survey with a maintenance guide concerning the various uses, viewpoints on the degree of the threat of extinction, the endogenous technical processing and marketing of leaves, fruits and other parts of $V$. doniana.

Computation of structural parameters of $V$. doniana

Density of trees $(N)$ : i.e. number of trees per hectare, expressed as stems/ha:

$$
N=\frac{n}{s},
$$

where $n$ is the number of trees in the plot area and $s$, the plot area expressed as ha.

Mean diameter (D): i.e diameter of the tree with mean basal area:

$$
D=\sqrt{\frac{1}{n} \sum_{i=1}^{n} d_{i}^{2}},
$$

Where $n$ is the number of trees found on the plot and $d_{i}$, the diameter of the $i^{\text {th }}$ tree. 
Blackman Index IB:

$I B=\frac{S^{2}}{m}$

Where $S^{2}$ is the variance of the tree-densities of the plots and $m$ the mean value of the treedensity.

\section{Pressure on species}

Due to multiple pressures of local people on $V$. doniana in disturbed riparian forests and parklands and based on our observations and considering their status in this area, we were interested in identifying the degree of pressure on species. The study involved adult individuals $(\mathrm{dbh} \geq 5 \mathrm{~cm}$ ) because it was difficult to measure the significant pressure on regenerations. The threat degree of economic endangered species $(D M E E M)$ is determined by the following formula:

$$
D M E E M=\frac{E I M+E I A}{E T} \times 100 \text {, }
$$

where,

DMEEM is the threat degree of economic endangered species;

EIM is the number of individuals maimed in the plot;

EIA is the number of individuals cut down in the plot; and

$E T$ is the total number of species in the plot.

\section{Statistical analysis}

Structural parameters of $V$. doniana were assessed and submitted to the analysis of variance (ANOVA) to compare the three targeted habitats. Data were $\log 10$ transformed to meet the normality and homogeneity of variances assumptions. Tukey test was also used to structure the average case of significant differences between habitats. Otherwise, regeneration data did not meet the conditions of normality of the analysis of variance despite the application of $\log 10$ transformation and the nonparametric test of Kruskal Wallis was used to compare habitats.

\section{RESULTS}

Dendrometric characteristics of $\boldsymbol{V}$. doniana The highest density of $V$. doniana occurred in disturbed riparian forest (11.27 stems/ha) and is 13.4 times higher than parklands density (0.84 stems/ha) and is slightly higher than natural riparian forest (8.67 stems/ha) (Table 2). $V$. doniana observed in the natural riparian forests were the largest $(45.76 \mathrm{~cm}$ diameter at breast height) and with an average diameter (by 7.78 and $1.53 \mathrm{~cm}$ ) higher than those of disturbed riparian forests and parklands.

Individuals observed in the natural riparian forests were larger in size with an average height of $11.06 \mathrm{~m}$ and were higher than trees in the disturbed riparian forests and in the parklands. The density of $V$. doniana in the agroforestry parkland was significantly lower than the natural riparian forests and disturbed riparian forests.

\section{Distribution of $V$. doniana}

The presence of $V$. doniana was noticed in the three villages considered in the study (Soroko, Banikoara and Founougo) and is observed in the following habitats: riparian forests in natural environments, banks of rivers in circles man (degraded or anthropized riparian forests) and agroforestry parklands but is not found in the shrub/tree savannah except in transition areas savannah-riparian forests. Blackman index is equal to 10.84 and suggests that $V$. doniana populations have aggregative distribution in the study area. However, the calculated Blackman index in parklands gave the value of $0.34<1$ indicating a random distribution in this habitat.

\section{Natural regeneration of $\boldsymbol{V}$. doniana}

The highest density of seedlings was found in the disturbed riparian forests (12.4 stems/ha) and was respectively 2 and 60 times higher than that obtained in natural riparian forests and agroforestry parklands (Table 3). The species showed a good ability of suckering in all habitats considered and almost all plants $(99.8 \%)$ were outside and seeds were mostly in situations where medium lighting (half-light, half-shade) or simply exposed to sun radiation.

\section{Degree of pressure on $\boldsymbol{V}$. doniana}

$V$. doniana was not threatened in natural riparian forests (Table 4). It was not 
the case in disturbed riparian forests and agro parks in which the DMEEM showed the rates higher than the critical threshold. These highest rates allow that almost all Vitex doniana populations were under pressures.

\section{Socio-economic importance of $\boldsymbol{V}$. doniana}

Vitex doniana was widely used by local population (Table 5).

The young leaves were harvested as leafy vegetable used in home cooking and for sale. The ball was usually sold for $25 \mathrm{CFA}$ francs (0.05 US\$) and sellers come to the turnover from 2,000 to 4,000 CFA francs (4 to 8 US\$) per day during the rainy season and
1,500 to 2,000 CFA francs (3 to 4 US\$) during the dry season. $V$. doniana fruits were well consumed in Banikoara district (100\%). Sellers did piles of 10 to 15 fruits according the size and sold each pile for $25 \mathrm{CFA}$ francs (0.05 US\$). The sale of $V$. doniana fruits generated income from 1,500 to 2,000 CFA francs (3 to 4 US\$) per day for individual traders. We did not observe the black plum syrup and pulp juice although we did not unaware the existence of this processing. The bark and roots of $V$. doniana are also sold in markets by traditional therapists. They did not have a standard price and this varies according to the needed quantity.

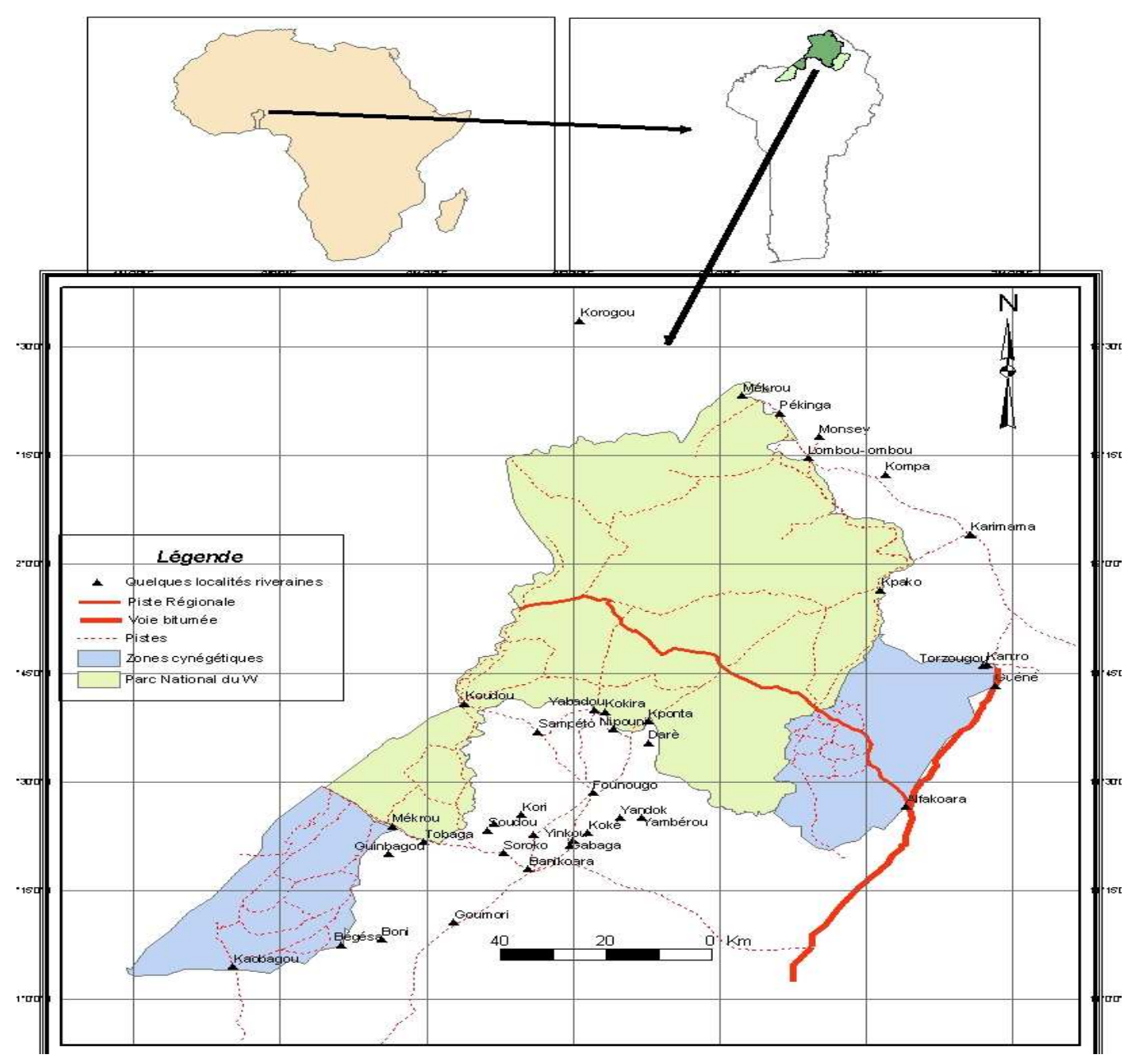

Figure 1: Location of study area.

Source: NPWD/CENAGREF Banikoara (2008) 
Table 1: Inventory design.

\begin{tabular}{lccc}
\hline Habitat type & Number of plots & Plot Size & Total area (ha) \\
\hline Undisturbed riparian forest. & 6 & $50 \mathrm{~m} \times 50 \mathrm{~m}$ & 1.50 \\
Disturbed riparian forest. & 11 & $50 \mathrm{~m} \times 50 \mathrm{~m}$ & 2.75 \\
Agroforestry parklands & 5 & $500 \mathrm{~m} \times 100 \mathrm{~m}$ & 25.00 \\
Total & 22 & & 29.25 \\
\hline
\end{tabular}

Table 2: Comparison of three habitats (ANOVA on logarithm of data by Turkey test): mean \pm standard deviation density, diameter and height of $V$. doniana populations.

\begin{tabular}{lccc}
\hline Habitat type & $\begin{array}{c}\text { Mean density } \\
(\text { stems/ha) }\end{array}$ & $\begin{array}{c}\text { Mean diameter } \\
(\mathbf{c m})\end{array}$ & $\begin{array}{c}\text { Mean height } \\
(\mathbf{m})\end{array}$ \\
\hline Undisturbed riparian forests. & $8.67 \pm 1.23 \mathrm{a}$ & $45.76 \pm 6.13 \mathrm{a}$ & $11.06 \pm 1.17 \mathrm{a}$ \\
Disturbed riparian forests. & $11.27 \pm 3.73 \mathrm{a}$ & $37.98 \pm 5.57 \mathrm{a}$ & $8.80 \pm 0.84 \mathrm{ab}$ \\
Agroforestry parklands & $0.84 \pm 0.24 \mathrm{~b}$ & $44.23 \pm 3.32 \mathrm{a}$ & $6.75 \pm 0.49 \mathrm{~b}$ \\
\hline P-value & $<0.000^{* * *}$ & $0.580 \mathrm{~ns}$ & $0.030^{*}$ \\
\hline Means in the same column with same letter are not significantly different $(\mathrm{P}<0.05)$ &
\end{tabular}

Table 3: Means \pm standard deviations of density grown-up trees and seedlings of natural regeneration of Vitex doniana in three habitats (stems / ha).

\begin{tabular}{lc|c}
\hline \multirow{2}{*}{ Habitats } & Grown-up trees $(\mathbf{D b h} \geq \mathbf{5} \mathbf{~ c m})$ & Seedlings $(\mathbf{D b h}<\mathbf{5} \mathbf{~ c m})$ \\
\cline { 2 - 3 } & Mean & Mean \\
\hline Undisturbed riparian forest. & $8.7 \pm 1.2$ & $6.0 \pm 6.07$ \\
Disturbed riparian forest. & $11.3 \pm 3.7$ & $12.4 \pm 15.8$ \\
Agroforestry parklands & $0.8 \pm 0.2$ & $0.2 \pm 0.2$ \\
\hline
\end{tabular}

Table 4: Degree of threat (\%) of Vitex doniana in various habitats.

\begin{tabular}{lccc}
\hline Parameters measured & $\begin{array}{c}\text { Indisturbed riparian } \\
\text { forests }\end{array}$ & $\begin{array}{c}\text { Disturbed riparian } \\
\text { forests }\end{array}$ & $\begin{array}{c}\text { Agroforestry } \\
\text { parklands }\end{array}$ \\
\hline EIM + EIA & 0 & 12 & 0.88 \\
Total numbers (stems/ha) & 8.66 & 19.27 & 0.92 \\
\hline DMEEM (\%) & 0 & 62,27 & 95.65 \\
\hline
\end{tabular}

DMEEM $=$ the threat degree of economic endangered species; EIM = the number of individuals maimed in the plot;

$\mathrm{EIA}=$ the number of individuals cut down in the plot; ET = the total number of species in the plot. 
Table 5: Various uses of Vitex doniana and response rates (\%).

\begin{tabular}{|c|c|c|c|}
\hline Part used & Uses & Actions envisaged & $(\%)$ \\
\hline Young leaves & Food & Leaf vegetables for making sauces & 100 \\
\hline \multirow{11}{*}{ Fresh leaves } & \multirow{6}{*}{ Medicinal } & Against malaria, headache and fever & 46 \\
\hline & & Stomachaches & 14 \\
\hline & & Fight tiredness & 16 \\
\hline & & Fight hemorrhoid & 2 \\
\hline & & Wound wash & 2 \\
\hline & & Vitamins for the body & 2 \\
\hline & \multirow[t]{3}{*}{ Magico-therapeutic } & Conquest of Women & 14 \\
\hline & & Chance and intelligence & 4 \\
\hline & & Against evil spirits & 2 \\
\hline & Cultural & Used to make alphas ink & 4 \\
\hline & Pastoral & Forage for goats, sheep and cattle & 16 \\
\hline Fruits (pulp) & Food & Consumed raw or dried & 100 \\
\hline Roots & medicinal & Stomachaches & 4 \\
\hline \multirow{8}{*}{ Barks } & \multirow{7}{*}{ Medicinal } & Stomachaches & 28 \\
\hline & & Against malaria, headache and fever & 18 \\
\hline & & Children diarrhea & 12 \\
\hline & & Aches, sore hip and ailments of the spine & 14 \\
\hline & & External and internal wounds (mouth, stomach) & 16 \\
\hline & & Hemorrhoid & 4 \\
\hline & & Dysentery, ulcer & 2 \\
\hline & Magico-therapeutic & Against evil spirits & 4 \\
\hline \multirow{3}{*}{$\begin{array}{l}\text { Branches and } \\
\text { trunks (wood) }\end{array}$} & Energetic & Firewood for cooking food & 68 \\
\hline & & Charcoal for cooking food & 10 \\
\hline & Construction & Roof frame & 4 \\
\hline Young stems & Hygienic & Vegetable brush & 50 \\
\hline
\end{tabular}

\section{DISCUSSION}

Aggregative distribution of $V$. doniana could be due to a strong preference for edaphic conditions (local differences in the environment). According to our investigations and calculated densities, $V$. doniana was relatively more abundant in riparian forests than elsewhere. Of course the riparian forests are the vegetation-types depending on edaphic conditions. According to several authors (Burkill, 2000; Arbonnier, 2002; El-Siddig et al., 2006), V. doniana colonizes a variety of environments, but has a preference for heavy soils and well-drained alluvial soils. Another particular observation is the scarcity of the species in savannah areas embedded in the sudanian region. According to Burkill (2000) and Akoègninou et al. (2006), V. doniana was found in the coastal savannah types. Apart from its zoochory dissemination by monkeys
(Papio anubis), bats and mammal rodents and its anthropochory dissemination by man, the species also realizes self-dissemination in the case in which fruits drop and germinate under the mother tree as was also noted by Glèlè Kakaï and Sinsin (2009) for Isoberlinia spp. These results were similar to those obtained by Bationo et al., 2005) in the study of the Isoberlinia doka distribution. In fact, I. doka showed aggregative distribution resulting from self-dissemination (autochory) and ability to suckering. The type of random distribution found in agroforestry parklands indicated that individuals of $V$. doniana in fields were not subjected to any factor of natural distribution. They were, rather, subjected to treatment of the owners of fields and their distribution depends on their uses.

The relatively high density of $V$. doniana in disturbed riparian forests may be 
explained by the fact that riparian forests were preferred habitats of the species, due to the passage of water (Burkill, 2000; Arbonnier, 2002). The anthropochory dissemination of the species could be its best form of dissemination. Indeed, when it grew and was not for sale, its fruits were mostly consumed locally and the seeds were thrown anywhere on the way back. This was an asset for the development of the species in disturbed riparian forests. According to the owners of fields, most individuals encountered existed before the erection of the fields. Thus human activities (Omeja et al., 2005), the agroforestry use (Pulido et al., 2001) and natural survival strategies intrinsic affected significantly $V$. doniana populations.

Concerning the average diameter of Vitex doniana, there is no significant difference in these three habitats. This may be explained by the fact that apart from the disturbed riparian forests that were primarily undisturbed riparian forests, fields were in areas of low altitudes (downstream) or close an disturbed riparian forest. This could also explain the non variability of $V$. doniana individuals in these habitats because the common ecological factor to these habitats is the presence of groundwater near, essential parameter for the survival of the species (Burkill, 2000; Arbonnier, 2002). In addition to diameter characteristics of black plum, we also observed that agroforestry parklands black plum which suffered from mutilation at the trunk level (debarking) regenerated a new bark (bloated appearance of the trunk). This phenomenon occurs in individuals barked of Khaya senegalensis and is an adaptive response of plant to the external conditions of the environment which, according to us, should not be taken into account in the study of the structure diameter of forest species.

Generally, the results indicate that there was no natural regeneration in the agroforestry parklands. From an ecological viewpoint, these results suggest that $V$. doniana populations grow slowly in different habitats, because, apart from the agro parks in which the species does not regenerate practically, $V$. doniana (adults and young plants) show normally the low densities in all habitats. The Banikoara district belongs to a SudanoSahelian region which was dominated by savannah vegetation types. This explains the low density of Vitex doniana populations. The regeneration is confronted with many environmental problems such as the weeding of young plants, the sensitivity of juveniles to bushfires, the human pressure on the natural stock of seeds by harvesting fruits and the pressure from herbivorous animals.

In Eyog Matig et al. (2003) opinion, $V$. doniana naturally regenerates by seeds or by stumps. It's a bright-light plant growing fast enough. Harvesting methods are not a problem for the conservation and survival of the species. Bushfires permit to break the skiff around the seed and to accelerate germination. Moreover, natural regeneration by seed (wind, wildlife, livestock...) comes up again after many unfavourable factors (Bellefontaine et al., 1999). Techniques of regeneration tend, nowadays, more and more towards vegetative multiplication by suckering which has more advantages in comparison with plantations. $V$. doniana is a species that has a good ability to suckering (Thies, 1995) and it would be interesting to explore possibilities of its propagation by suckering faced with difficulties of natural regeneration.

$V$. doniana was threatened in disturbed habitats (agroforestry parklands and disturbed riparian forests) and was not endangered in the undisturbed riparian forests. Reasons for this situation were mainly the use of leaves of this species for food that led to the pruning of all leafy branches and for medicinal purposes by the harvesting of bark and roots.

$V$. doniana is used by village dwellers, especially its fruits and leaves which are also marketed. The uncontrolled use of fruits, leaves, barks and woods of the species is one of the factors that affect the mature and young plants and could have negative impacts on the structure of populations. Despite its importance, $V$. doniana was not the subject of 
a large-scale processing of its products as in other regions of the world. According to Arbonnier (2002) and Ruffo et al. (2002), V. doniana was a protected species in fallow and often planted as fruit tree near homes

In conclusion, $V$. doniana is a multipurpose species protected by Banikoara population for socio-economic reasons. The study of the structure and natural regeneration of the populations of Vitex doniana contribute to a better understanding of the species and its uses. However, recorded and protected individuals in disturbed environment (agroforestry parklands and riparian forests or degraded river banks), were spontaneous and under intensive pressures. No activity on planting new subjects for future has been mentioned by local population. For better conservation and sustainable management of $V$. doniana, it's advisable that authorities in charge of the forestry administration work for the production and freely distribution of seedlings of this species to local people, encourage local population to plant, to protect and to put a lot of care on the natural regeneration in their fields or in their home gardens and finally, to study the characteristics of vegetative propagation by suckering of the species and to identify its status in IUCN criteria.

\section{REFERENCES}

Akoègninou A, Van Der Burg WJ, Van Der Maesen LJG, Adjakidjè V, Essou JP, Sinsin B, Yèdomonhan H. 2006. Flore Analytique du Bénin. Backuys Publishers. Arbonnier M. 2002. Arbres Arbustes et Lianes des Zones Sèches d'Afrique de l'Ouest. CIRAD-MNHN.

Bationo B A, Ouedraogo SJ, Nsomé A, Pallo F, Boussim IJ. 2005. Régénération naturelle d'Isoberlinia doka Craib. et Staff. Dans la forêt classée du Nazinon (Burkina Faso). Cahiers d'Etudes et de Recherches Francophones/Agricultures, 14(3): 297-304.

Bellefontaine R, Nicolini EA, Petit S. 1999. Réduction de l'érosion par l'exploitation de l'aptitude à drageonner de certains ligneux des zones tropicales sèches. Bulletin Réseau Erosion, 19: 342-352.

Burkill HM. 2000. The Useful PLants of West Tropical Africa (2nd edn). Volume 5, Families S-Z, Addenda. Royal Botanic Gardens: Kew, Richmond, United Kingdom.

Egbekun MK, Akowe JI, Ede RJ. 1996. Physico-chemical and sensory properties of formulated syrup from black plum (Vitex doniana) fruit. Plant Foods for Human Nutrition, 49(4): 301-306.

El-Siddig K, Gunasena HPM, Prasad BA, Pushpakurama DKNG, Ramana KVR, Vijayanand P, Williams JT. 2006. Tamarind, Tamarindus indica L. Southampton Centre for Underutilised Crops: Southampton, UK.

Eyog Matig O, Gaoué OG, Dossou B. 2002. Réseaux "Espèces Ligneuses Alimentaires". Compte Rendu de la Première Réunion du Réseau Tenue du 11-13 Décembre 2000 au CNSF Ouagadou, Burkina Faso 241. Institut International des Ressources Phytogénétiques. ISBN 92-9043-5526235.

Eyog Matig O, Ndoye O, Kengue J, Awono A. 2003. Les Fruitiers Forestiers Comestibles du Cameroun. IPGRI/SAFORGEN.CIFOR.IRAD.

Eyog Matig O, Ouédraogo AS. 1999. State of Forest Genetic Resources in the Sahelian and North-Sudanian zone of Africa. FAO, Rome, Italy. Forest Genetic Resources, 27: 27-33.

FAO. 2006a. Global Forest Ressources Assessment 2005: progress towards sustainable forest management, (FRA 2005). Etude FAO, Forestry $\mathrm{n}^{\circ} 147$, Rome, Italy.

Glèlè Kakaï R, Sinsin B. 2009. Structural description of two Isoberlinia dominated vegetation types in the Wari-Maro Forest Reserve (Benin). South African Journal of Botany, 75: 43-51. 
Nyadoi P. 2005. Population structure and socio-économic importance of Tamarindus indica in Tharaka District, Eastern Kenya. M.Sc. Thesis. Makarere University, Uganda.

Omeja P, Obua J, Cunningham AB. 2005. Demand and supply of wood for drum making in Central Uganda. International Forestry Review, 7(1): 1-200.

Pulido FJ, Diaz M, Hidalgo de Trucios SJ. 2001. Size structure and regeneration of Spanish holm oak Quercus ilex forest and dehesas: Effects of agroforestry use on their long term sustainability. Forest Ecology and Management, 146: 1-13.
Ruffo CK, Birnie A, Tengnäs B. 2002. Edible wild plants of Tanzania: Technical Hand Book n ${ }^{\circ} 27$, RELMASIDA.

Sinsin B, Eyog Matig O, Assogbadjo AE, Gaoué OG, Sinadouwirou T. 2004. Dendrometric characteristics as indicators of pressure of Afzelia africana Sm. Dynamic changes in trees found in different climate zones of Benin. Biodiversity and Conservation, 13(8): 1555-1570.

Thies E. 1995. Principaux ligneux (agro-) forestiers de la Guinée. Zone de transition. Schriftenreihe de GTZ N ${ }^{\circ} 253$. 